\title{
Relative effects of LDL-C on ischemic stroke and coronary disease
}

\section{A Mendelian randomization study}

Elsa Valdes-Marquez, PhD, Sarah Parish, DPhil, Robert Clarke, FRCP, Traiani Stari, PhD, Bradford B. Worrall, MD, METASTROKE Consortium of the ISGC, and Jemma C. Hopewell, PhD

Neurology ${ }^{\circledR}$ 2019;92:e1176-e1187. doi:10.1212/WNL.0000000000007091

\author{
Correspondence \\ Dr. Hopewell \\ Jemma.Hopewell@ \\ ndph.ox.ac.uk
}

\section{Abstract \\ Objective}

To examine the causal relevance of lifelong differences in low-density lipoprotein cholesterol (LDL-C) for ischemic stroke (IS) relative to that for coronary heart disease (CHD) using a Mendelian randomization approach.

\section{Methods}

We undertook a 2-sample Mendelian randomization, based on summary data, to estimate the causal relevance of LDL-C for risk of IS and CHD. Information from 62 independent genetic variants with genome-wide significant effects on LDL-C levels was used to estimate the causal effects of LDL-C for IS and IS subtypes (based on 12,389 IS cases from METASTROKE) and for CHD (based on 60,801 cases from CARDIoGRAMplusC4D). We then assessed the effects of LDL-C on IS and CHD for heterogeneity.

\section{Results}

A $1 \mathrm{mmol} / \mathrm{L}$ higher genetically determined LDL-C was associated with a 50\% higher risk of $\mathrm{CHD}$ (odds ratio [OR] 1.49, 95\% confidence interval [CI] 1.32-1.68, $p=1.1 \times 10^{-8}$ ). By contrast, the causal effect of LDL-C was much weaker for IS (OR 1.12, 95\% CI 0.96-1.30, $p=0.14 ; p$ for heterogeneity $=2.6 \times 10^{-3}$ ) and, in particular, for cardioembolic stroke (OR 1.06, $95 \%$ CI $0.84-1.33, p=0.64 ; p$ for heterogeneity $=8.6 \times 10^{-3}$ ) when compared with that for CHD.

\section{Conclusions}

In contrast with the consistent effects of LDL-C-lowering therapies on IS and CHD, genetic variants that confer lifelong LDL-C differences show a weaker effect on IS than on CHD. The relevance of etiologically distinct IS subtypes may contribute to the differences observed.

From the Clinical Trial Service Unit and Epidemiological Studies Unit (E.V.-M., S.P., R.C., T.S., J.C.H.) and MRC Population Health Research Unit (S.P.), Nuffield Department of Population Health, University of Oxford, UK; and Departments of Neurology and Public Health Sciences (B.B.W.), University of Virginia School of Medicine, Charlottesville, VA.

Go to Neurology.org/N for full disclosures. Funding information and disclosures deemed relevant by the authors, if any, are provided at the end of the article. The Article Processing Charge was funded by the British Heart Foundation under the COAF Partnership. 


\section{Glossary}

CHD = coronary heart disease $\mathbf{C I}=$ confidence interval; HDL-C = high-density lipoprotein cholesterol; GLGC = Global Lipids Genetics Consortium; IS = ischemic stroke; LDL-C = low-density lipoprotein cholesterol; MR-Egger = Mendelian randomization-Egger; MR-PRESSO = Mendelian randomization-Pleiotropy Residual Sum and Outlier; OR = odds ratio.

Stroke is a heterogeneous collection of clinically related but distinct disorders, with ischemic stroke (IS) representing $70 \%-90 \%$ of all strokes. ${ }^{1,2}$ Different IS subtypes have distinct underlying pathologies that likely reflect differences in the importance of underlying risk factors, such as hypertension and dyslipidemia, as well as in genetic determinants. ${ }^{3-6}$

Randomized trials of statin therapy have demonstrated that lowering low-density lipoprotein cholesterol (LDL-C) by 1 $\mathrm{mmol} / \mathrm{L}$ reduces the risk of both IS and coronary heart disease (CHD) by about $20 \%{ }^{7}$ Other LDL-C-lowering therapies, such as ezetimibe and PCSK9 inhibitors, also yield comparable reductions in IS and CHD risk. ${ }^{8,9}$ In contrast, observational studies have found stronger effects of LDL-C on CHD than on IS, ${ }^{10}$ and potential heterogeneity in the effects of cholesterol on different IS subtypes. ${ }^{6}$ Therefore, further evidence is needed to determine whether LDL-C has comparable causal consequences for IS and CHD.

Mendelian randomization avoids many of the potential biases of observational studies, such as reverse causation and confounding. Mendelian randomization studies use genetic variants as instrumental variables that reflect lifelong differences in exposure to a risk factor, in order to examine its causal relevance for an outcome of interest. However, Mendelian randomization can be sensitive to pleiotropy, in which genetic variants are associated with multiple risk factors on different biological pathways. Mendelian randomization studies have been widely used to examine risk factors for $\mathrm{CHD},{ }^{11-14}$ but studies of IS have been limited. ${ }^{15-17}$

The present Mendelian randomization study examines the causal relevance of LDL-C for IS and compares it with that for CHD.

\section{Methods}

\section{Study populations}

We obtained genome-wide association estimates for LDL-C, high-density lipoprotein cholesterol (HDL-C), and triglycerides from the Global Lipids Genetics Consortium (GLGC), based on up to 188,577 participants of European ancestry. ${ }^{18}$ The effects of these genetic variants on CHD were examined in the CARDIoGRAMPlusC4D Consortium including up to $60,801 \mathrm{CHD}$ cases and 123,504 controls from 48 studies of predominantly European ancestry. ${ }^{19}$ Similarly, the effects on IS and IS subtypes were examined in METASTROKE, a collaboration of the International Stroke Genetics Consortium, which brings together genome-wide data on a total of 12,389 IS cases and 62,004 controls of European ancestry from across 15 studies. ${ }^{20}$ The majority of IS cases had brain imaging confirmation. Approximately $50 \%$ of cases had IS subtype information (2,365 cardioembolic, 2,167 large artery, and 1,894 small vessel stroke cases) based on Trial of Org 10172 in Acute Stroke Treatment classifications. ${ }^{21}$ Additional phenotype descriptions and details of individual studies, including data collection and genetic data quality control procedures, are reported elsewhere. ${ }^{20}$

\section{Standard protocol approvals, registrations, and patient consents}

Each study included in the consortia was approved by an institutional review board, and all patients provided informed consent.

\section{Selection of LDL-C associated genetic variants}

We selected genetic variants with genome-wide significant $\left(p<5 \times 10^{-8}\right)$ associations with LDL-C in the GLGC metaanalysis and that were available in both the CARDIoGRAMplusC4D and METASTROKE datasets. Of these 2,243 genetic variants, we identified 99 independent variants $\left(r^{2}<0.01\right.$ within $\pm 1,000 \mathrm{~kb}$ ) using the clumping method implemented in PLINK1.9 and 1,000 Genomes Project Phase 3 (EUR) reference population. ${ }^{22,23}$ Finally, to identify variants with LDL-C-specific lipid effects (and avoid pleiotropy through effects on other lipid pathways), we excluded the 37 variants with significant effects on HDL-C or triglycerides $(p<0.0005$ based on Bonferroni correction for 99 variants). Hence, the primary analyses were restricted to the 62 variants with LDLspecific effects, with sensitivity analyses performed using all 99 variants that were independently associated with LDL-C (table e-1; doi.org/10.5061/dryad.8076h3r). ${ }^{18}$

\section{Statistical analysis}

Per-allele effects for LDL-C were extracted from GLGC and converted from the published SD units to $\mathrm{mmol} / \mathrm{L}$ (1 SD unit equating to $\sim 1 \mathrm{mmol} / \mathrm{L})$. Per-allele effects of the variants on CHD were taken from CARDIoGRAMplusC $4 \mathrm{D}^{19}$ and on IS (and IS subtypes) from METASTROKE. ${ }^{20}$ To account for multiple testing, we used a predefined $p$ value threshold of $p<$ 0.0005 to indicate statistically significant associations of individual variants with risk of disease, and report all effects with respect to the LDL-C increasing allele unless otherwise stated. The percentage of variance explained in LDL-C was estimated by $2 \times$ (effect on LDL-C in SD units) ${ }^{2} \times$ minor allele frequency $\times(1-$ minor allele frequency $),{ }^{24}$ and power calculations for $p<0.01$ were estimated from the variance explained and sample size. ${ }^{25}$ 
Causal effects on disease outcomes per $1 \mathrm{mmol} / \mathrm{L}$ genetically higher LDL-C were estimated using the random-effects inverse-variance weighted method for summarized data (in which all genetic variants included are assumed to be valid instrumental variables). ${ }^{26}$ To account for the multiple outcomes tested, a predefined $p$ value threshold of $p<0.01$ was used to indicate statistically significant causal associations. We conducted methodologic sensitivity analyses ${ }^{27,28}$ using the Mendelian randomization-Egger (MR-Egger) method (in which all genetic variants are permitted to be invalid instrumental variables, provided that the pleiotropic and risk factor effects of the variants are independently distributed-known as the instrument strength independent of direct effect assumption-and allows assessment of directional pleiotropic bias $)^{29,30}$; the weighted median method (in which $50 \%$ of the genetic variants are permitted to be invalid instrumental variables) $)^{31}$ and the multivariate method (in which potentially pleiotropic effects on HDL-C and triglycerides are allowed for by including terms for each lipid (table e-1; doi.org/10.5061/dryad.8076h3r) in the estimation of the causal effects, while fixing the intercept term as zero). ${ }^{32}$ The Mendelian randomization-Pleiotropy Residual Sum and Outlier (MR-PRESSO) method (which performs a pleiotropy residual sum and outlier test and allows detection and correction of pleiotropy by outlier removal) was also used to evaluate potential pleiotropy and identify outlying variants that were then excluded from the analyses. ${ }^{33}$ Heterogeneity between the causal effects of individual variants, as well as comparisons between the causal effects of LDL-C on CHD vs IS (and IS subtypes), were tested using the Cochran Q statistic. ${ }^{27}$ All statistical analyses were performed in SAS v9.3 or R v3.4.3.

\section{Data availability}

The data included in the reported analyses have been made publicly available (also see Acknowledgement for additional details on data access).

\section{Results}

\section{Effects of LDL-C genetic variants on CHD, IS, and IS subtypes}

The effects of the 62 individual genetic variants on LDL-C levels varied by 5 -fold, ranging from $0.02 \mathrm{mmol} / \mathrm{L}$ to $0.10 \mathrm{mmol} / \mathrm{L}$ per allele (table e-1; doi.org/10.5061/dryad.8076h3r), and in combination explained about $4 \%$ of the variance in LDL-C. Despite limited power to detect risk associations with individual variants, 8 variants were associated with $\mathrm{CHD}$ and 2 with IS $(p<0.0005$; table e-2; doi.org/10.5061/dryad.8076h3r). The effects of the 62 variants on IS and IS subtypes were consistently weaker than their effects on $\mathrm{CHD}$ (figure 1 and table e- 3 and figures e- 1 and e-2; doi.org/10.5061/dryad.8076h3r).

\section{Causal effects of LDL-C on CHD, IS, and IS subtypes}

Genetically determined LDL-C was associated with about a 50\% higher risk of CHD per $1 \mathrm{mmol} / \mathrm{L}$ (odds ratio [OR] $1.49,95 \%$ confidence interval [CI] 1.32 to $1.68 ; p=1.1 \times$ $10^{-8}$ ) but, by contrast, had no effect on IS (OR 1.12 , 95\% CI 0.96 to $1.30 ; p=0.14$ ). There were also no effects of genetically determined LDL-C on any of the individual subtypes of IS (figure 2).

The effect of LDL-C on IS was weaker than that on CHD $\left(p\right.$ for heterogeneity $\left.=2.6 \times 10^{-3}\right)$, and in particular on

Figure 1 Effects of genetic variants on coronary heart disease and ischemic stroke risk vs low-density lipoprotein cholesterol (LDL-C) levels
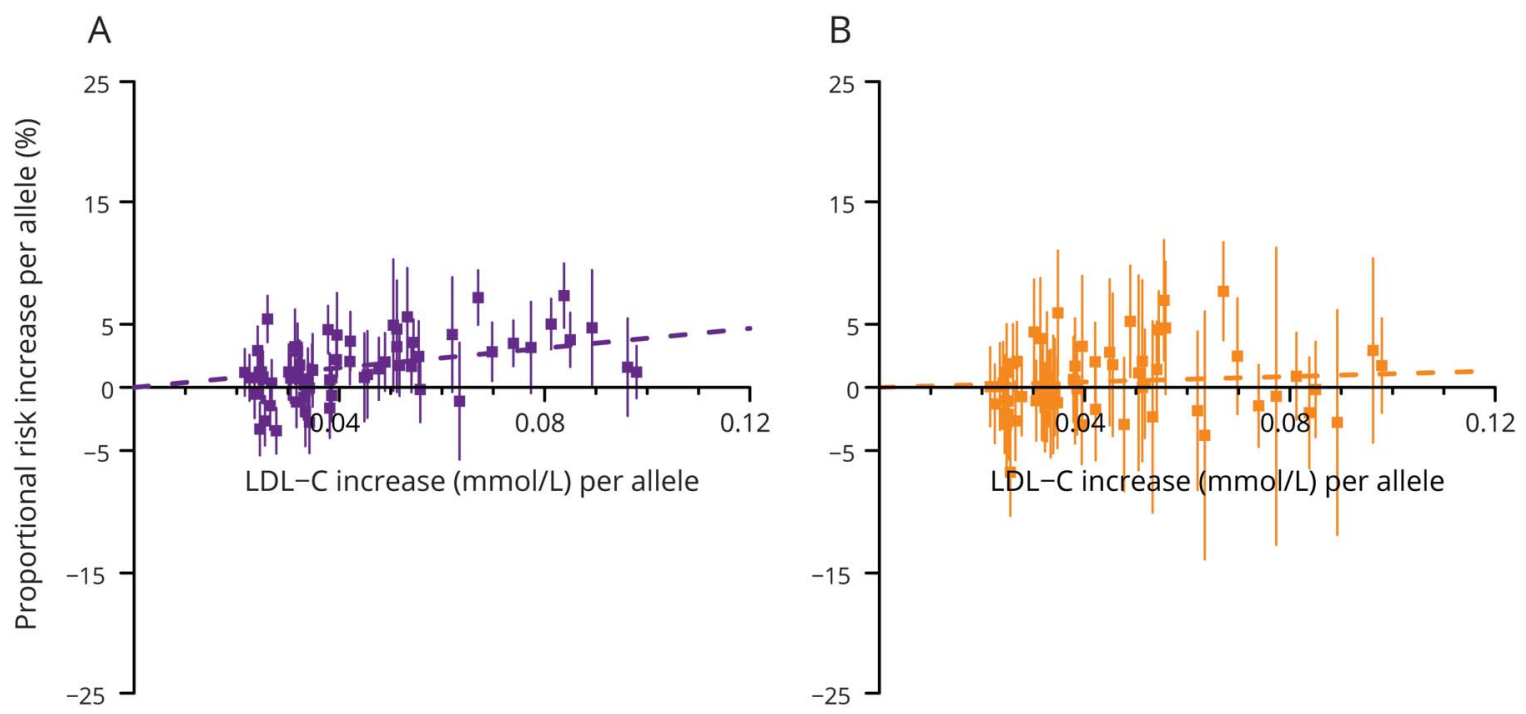

Figures are shown separately for (A) coronary heart disease and (B) ischemic stroke. Effects of the 62 individual genetic variants in the primary analysis are shown per LDL-C increasing allele. 
cardioembolic stroke ( $p$ for heterogeneity $=8.6 \times 10^{-3}$ ), whereas the effects of LDL-C on large artery stroke and small vessel stroke were compatible with the magnitude of the effect observed for CHD ( $p$ for heterogeneity $=0.05$ and 0.06 , respectively; figure 2 ). Furthermore, given $>99 \%$ power to detect a $30 \%$ increase in risk of IS at $p<0.01$ (equivalent to the lower limit of the CI for CHD), these analyses can exclude a causal effect of LDL-C on total IS of the same magnitude as on CHD. However, given comparatively little power $(<50 \%)$ to detect $30 \%$ causal effects for separate IS subtypes, comparable effects of LDL-C on CHD and particular IS subtypes cannot be excluded.

\section{Sensitivity analyses}

Sensitivity analyses were undertaken based on an instrument including 99 LDL-C-associated variants (of which 37 were also associated with HDL-C or triglycerides). This genetic instrument explained $11 \%$ of the variance in LDL-C, and was strongly influenced by the TOMM40/APOE locus, which represented $\sim 2 \%$ of the variance in LDL-C. The estimates of the LDL-C causal effects on disease outcomes did not differ meaningfully from the primary analysis involving 62 variants with LDL-C-specific effects (figure e-3; doi.org/10.5061/ dryad.8076h3r). However, they were slightly weaker, 1.05 (95\% CI 0.96 to 1.15 ) vs 1.12 (95\% CI 0.96 to 1.30 ) for IS per $1 \mathrm{mmol} / \mathrm{L}$ higher LDL-C, and showed greater heterogeneity between individual variant causal effects than the primary analysis instrument $\left(p=1.0 \times 10^{-5}\right.$ vs $p=2.5 \times$ $10^{-3}$ ). A similar pattern was also observed when comparing the causal effects of the different genetic instruments for CHD.

In the primary analyses, the LDL-C causal effect estimates for CHD and IS across genetic variants obtained by the inverse-variance weighted approach were consistent with those obtained by the weighted median and multivariate Mendelian randomization methods (table 1). There was no evidence of directional pleiotropy for either CHD (bias = $-0.012, \mathrm{p}=0.07$ ) or IS (bias $=-0.014, p=0.08$ ). The causal estimates from the MR-Egger analysis were greater than those obtained by other methods. However, MR-Egger results should be interpreted with caution due to potential bias from outlying variants. The exclusion of outlying variants identified by MR-PRESSO reduced the causal estimates from MR-Egger, as well as the estimates of pleiotropic bias (bias $=-0.006, p=0.23$ for CHD and bias $=-0.008, p=$ 0.26 for IS). The heterogeneity between variants was also attenuated after making these exclusions $\left(p=1.7 \times 10^{-9}\right.$ vs $1.2 \times 10^{-5}$ for CHD and $p=2.5 \times 10^{-3}$ vs 0.18 for IS). Based on the 99-variant instrument, estimates were consistent across all the methods explored and there was no evidence of directional pleiotropy.

Figure 2 Effects of genetically determined low-density lipoprotein cholesterol (LDL-C) on vascular disease and ischemic stroke subtypes

Vascular disease

Coronary heart disease

Ischemic stroke

12,389

Ischemic stroke subtypes

Events

60,801
Cardioembolic

Large artery

Small vessel
2,365

2,167

1,894
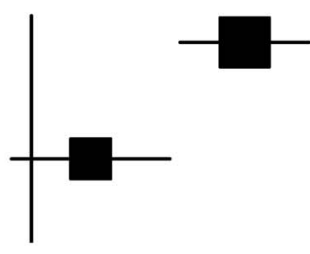

Odds ratio $(95 \% \mathrm{Cl})$ per $1 \mathrm{mmol} / \mathrm{L}$ higher LDL-C
$1.12(0.96-1.30)$

$.49(1.32-1.68)$

$.06(0.84-1.33)$

$1.10(0.82-1.47)$

$1.14(0.88-1.48)$

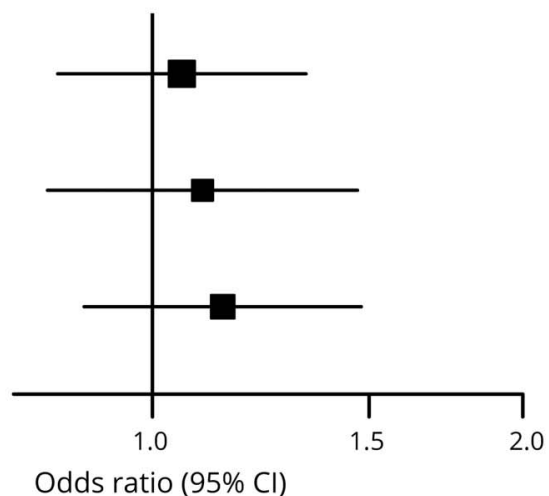

Odds ratio $(95 \% \mathrm{Cl})$ 
Table 1 Sensitivity analyses estimating the causal effects of low-density lipoprotein cholesterol (LDL-C) on coronary heart disease and ischemic stroke

\begin{tabular}{|c|c|c|c|c|}
\hline & \multicolumn{2}{|c|}{$\begin{array}{l}\text { Primary analyses ( } 62 \text { variants explaining } 4 \% \\
\text { of the variance in LDL-C) }\end{array}$} & \multicolumn{2}{|c|}{$\begin{array}{l}\text { Sensitivity analyses ( } 99 \text { variants explaining } \\
11 \% \text { of the variance in LDL-C) }\end{array}$} \\
\hline & $\begin{array}{l}\text { OR }(95 \% \mathrm{Cl}) \text { per } \\
1 \mathrm{mmol} / \mathrm{L} \text { higher } \\
\text { LDL-C }\end{array}$ & $p$ & $\begin{array}{l}\text { OR }(95 \% \mathrm{Cl}) \text { per } \\
1 \mathrm{mmol} / \mathrm{L} \text { higher } \\
\text { LDL-C }\end{array}$ & $p$ \\
\hline \multicolumn{5}{|l|}{ CHD } \\
\hline $\begin{array}{l}\text { Inverse-variance weighted Mendelian } \\
\text { randomization }\end{array}$ & $1.49(1.32,1.68)$ & $1.1 \times 10^{-8}$ & $1.47(1.37,1.59)$ & $4.5 \times 10^{-17}$ \\
\hline Inverse-variance weighted MR-PRESSOa & $1.48(1.35,1.63)$ & $4.8 \times 10^{-11}$ & $1.57(1.48,1.66)$ & $8.8 \times 10^{-27}$ \\
\hline Weighted median Mendelian randomization & $1.58(1.41,1.77)$ & $6.1 \times 10^{-11}$ & $1.50(1.38,1.63)$ & $4.4 \times 10^{-16}$ \\
\hline Multivariate Mendelian randomization & $1.53(1.34,1.76)$ & $5.0 \times 10^{-8}$ & $1.45(1.34,1.58)$ & $6.2 \times 10^{-15}$ \\
\hline MR-Egger & $1.88(1.42,2.50)$ & $3.1 \times 10^{-5}$ & $1.51(1.33,1.71)$ & $2.2 \times 10^{-9}$ \\
\hline MR-Egger MR-PRESSO ${ }^{a}$ & $1.68(1.34,2.13)$ & $3.3 \times 10^{-5}$ & $1.70(1.53,1.89)$ & $4.4 \times 10^{-16}$ \\
\hline \multicolumn{5}{|l|}{ Ischemic stroke } \\
\hline $\begin{array}{l}\text { Inverse-variance weighted Mendelian } \\
\text { randomization }\end{array}$ & $1.12(0.96,1.30)$ & 0.14 & $1.05(0.96,1.15)$ & 0.28 \\
\hline Inverse-variance weighted MR-PRESSO ${ }^{a}$ & $1.09(0.84,1.33)$ & 0.17 & $1.05(0.98,1.12)$ & 0.18 \\
\hline Weighted median Mendelian randomization & $1.08(0.89,1.31)$ & 0.42 & $1.01(0.91,1.13)$ & 0.85 \\
\hline Multivariate Mendelian randomization & $1.16(0.98,1.38)$ & 0.09 & $1.06(0.96,1.16)$ & 0.24 \\
\hline MR-Egger & $1.48(1.05,2.10)$ & 0.03 & $1.10(0.96,1.27)$ & 0.17 \\
\hline MR-Egger MR-PRESSO ${ }^{a}$ & $1.28(0.94,1.74)$ & 0.11 & $1.06(0.94,1.19)$ & 0.34 \\
\hline
\end{tabular}

Abbreviations: $\mathrm{CHD}=$ coronary heart disease; $\mathrm{Cl}=$ confidence interval; MR-Egger = Mendelian randomization-Egger; MR-PRESSO = Mendelian randomization-Pleiotropy Residual Sum and Outlier; OR = odds ratio.

a MR-PRESSO analyses were based on 10,000 simulations and a significance threshold of $p<0.05$. In primary analyses, MR-PRESSO identified 5 outliers (rs1250229, rs4530754, rs579459, rs7770628, and rs7953150) for CHD and 2 (rs579459 and rs795310) for ischemic stroke. The exclusion of these variants reduced the horizontal pleiotropy (global test $p$ value [observed residual sum of squares] from $p<0.0001$ [211.82] to $p=0.0001$ [117.60] for CHD and from $p=$ $0.003[100.26]$ to $p=0.175$ [71.37] for ischemic stroke). The resulting instrumental variables continued to explain $\sim 4 \%$ of the variance in LDL-C levels. In sensitivity analyses, MR-PRESSO identified 10 outliers (rs1250229, rs1531517, rs3125055, rs3184504, rs4530754, rs579459, rs7254892, rs7770628, rs7953150, and rs4970712) for CHD and 3 (rs3184504, rs579459, and rs795310) for ischemic stroke. The exclusion of these variants reduced the horizontal pleiotropy (global test $p$ value [observed residual sum of squares] from $p<0.0001$ [369.16] to $p<0.0001$ [151.81] for CHD and from $p<0.0001$ [173.36] to $p=$ 0.062 [119.55] for ischemic stroke). The resulting instrumental variables for CHD and stroke explained $\sim 9 \%$ and $11 \%$ of the variance in LDL-C levels, respectively. Tests for heterogeneity between causal estimates for CHD and ischemic stroke: inverse-variance weighted Mendelian randomization $(p=2.6 \times$ $\left.10^{-3}\right)$, inverse-variance weighted MR-PRESSO $\left(p=1.8 \times 10^{-4}\right)$, weighted median Mendelian randomization $\left(p=5.3 \times 10^{-4}\right)$, multivariate Mendelian randomization $(p=0.01)$, MR-Egger $(p=0.28)$, and MR-Egger MR-PRESSO $(p=0.15)$.

Evidence of heterogeneity between the causal effects of LDL$\mathrm{C}$ on $\mathrm{CHD}$ vs IS was consistent for all analysis approaches, with the exception of MR-Egger in the primary analyses and without exception for the 99-variant sensitivity analysis demonstrating weaker effects of genetically determined LDL$\mathrm{C}$ on IS than on CHD (table 1).

\section{Comparing observational, randomized, and genetic evidence}

The effects of genetically determined LDL-C (per $1 \mathrm{mmol} / \mathrm{L}$ higher) on CHD and IS in the present study were similar to the corresponding effects reported for equivalent LDL-C changes in observational studies (figure 3), ${ }^{7,10}$ As observed in the genetic data, the observational associations of LDL-C with stroke were weaker than those with $\mathrm{CHD}\left(p=3.2 \times 10^{-8}\right)$. In contrast, there was no such heterogeneity between the effects observed in the statin trials $(p=0.20)$.

\section{Discussion}

This Mendelian randomization study provides a large-scale comparison of the lifelong effects of LDL-C on risk of vascular disease, and demonstrates that genetically determined LDL-C has a weaker effect on IS than on CHD. Furthermore, these results were robust to the selection of LDL-C genetic variants used to estimate the causal effect as well as to different statistical approaches to Mendelian randomization analyses.

Observational evidence suggests that in addition to a differential effect of cholesterol on IS and hemorrhagic stroke, the effect of cholesterol on IS varies by subtype. ${ }^{6,34}$ In contrast, the Stroke Prevention by Aggressive Reduction in Cholesterol Levels (SPARCL) ${ }^{35}$ trial reported that atorvastatin effectively prevented recurrent stroke (independently of 
the subtype of the previous stroke), but did not indicate that statins had differential effects on specific IS subtypes. However, genetic data from the SiGN study suggested a somewhat stronger effect of LDL-C on large artery stroke than on other IS subtypes. ${ }^{15}$ The present genetic study, which includes $\sim 7,000$ independent IS cases not previously reported in the SiGN study, showed a nonsignificant $12 \%$ higher risk on $I S$ per $1 \mathrm{mmol} / \mathrm{L}$ genetically determined LDL-C, and relatively consistent effects of LDL-C across IS subtypes. However, this analysis had limited power to assess the causal effects of LDL-C on specific IS subtypes and on the compatibility with the effect on CHD. Furthermore, differences in the ethnicity of participants (SiGN included some non-European participants), in the instrumental variables used and clumping criteria (in which the present study was more stringent to avoid overweighting), as well as unknown differences in vascular risk factor distributions may contribute to discrepancies between the studies. Thus, given the biological plausibility of differential effects of LDL-C on different IS subtypes (and previous evidence that genetic determinants of stroke are commonly subtype-specific ${ }^{20}$ ), larger scale Mendelian randomization studies are still needed to clarify the lifelong effects of LDL-C on etiologically distinct IS subtypes. In addition, IS subtype information is needed in large-scale randomized trials of LDL-modifying therapies to directly assess their effects on different subtypes of IS.

The analogy between Mendelian randomization and randomized clinical trials is commonly used. However, Mendelian randomization studies examine the lifelong cumulative effects of a risk factor, while clinical trials examine the shortterm effect of a therapy. Consequently, the effect estimates from Mendelian randomization studies and randomized trials are not expected to be directly comparable. Mendelian randomization can assess the causal relevance of risk factors and help to anticipate relative effects of therapies on different disease outcomes, by studying genetic variants that have direct effects on a risk factor or that mimic therapeutic interventions, and by exploring the effects for one outcome relative to another, as in the present study. ${ }^{36}$

Genetic variants that affect LDL-C levels via various biological pathways were combined in the analyses described to provide a strong instrument for LDL-C, under the

Figure 3 Effects of low-density lipoprotein cholesterol (LDL-C) on vascular disease in prospective studies, randomized statin trials, and genetic studies

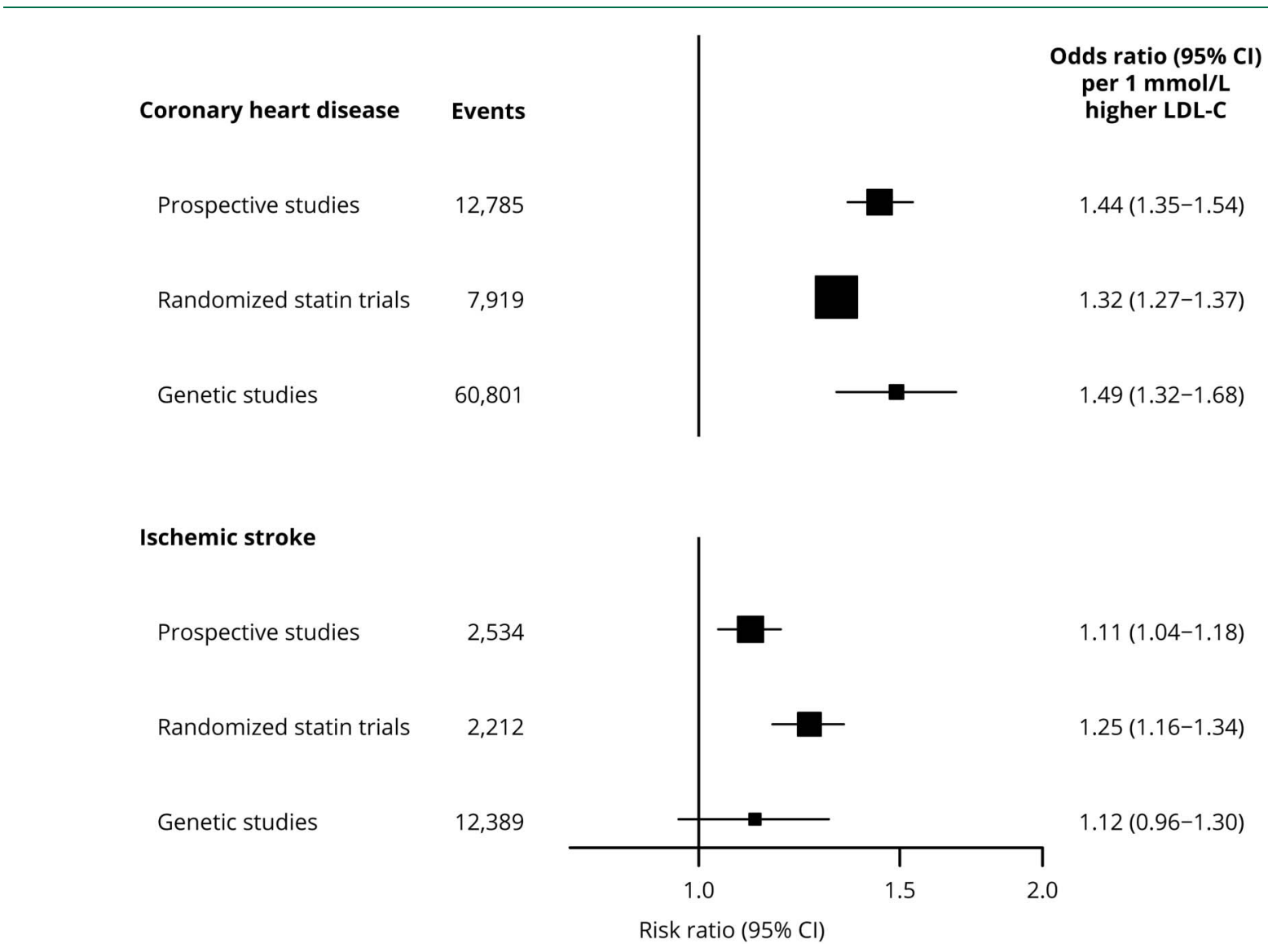

Genetic effect of LDL-C on disease was estimated based on 62 variants associated with LDL-C (see primary analysis methods). Estimates from prospective studies are shown for usual levels of non-high-density lipoprotein cholesterol. ${ }^{10}$ Estimates from randomized statin trial for coronary heart disease are based on major coronary events (coronary death or nonfatal myocardial infarction). ${ }^{7}$ Estimates from genetic studies are taken from figure 2 . Cl $=$ confidence interval. 
assumption that LDL-C has consistent effects across all these mechanisms. However, genetic studies examining the effects of specific therapeutic targets that affect LDL-C and other biomarkers are also important for drug target evaluation. Recent studies examining instruments based on specific genes that mimic the effects of lipid-modifying therapies, such as PCSK9, HMGCR, and NPC1L1, have shown weaker effects on IS than on CHD, but also suggest that the different pathways involved may affect stroke subtypes differentially. ${ }^{15,37,38}$ A study of the combined effects of CETP and HMGCR has also suggested that the benefits of lowering LDL-C may depend on the reduction in apoBcontaining lipoprotein particles. ${ }^{39}$

The effects of LDL-C on IS were comparable to those on CHD in randomized trials of statin therapy, but were smaller for IS than for CHD in this genetic study (figure 3). Clinical trials of lipid-modifying therapies have typically recruited a high proportion of participants with, or at high risk of, coronary heart disease, and hence such patients are likely to have high levels of atherosclerosis. In the Cholesterol Treatment Trialists' meta-analysis of randomized statin trials, over $50 \%$ of participants had established CHD, and $70 \%$ had $\geq 10 \% 5$-year risk of a major vascular event. ${ }^{40}$ By contrast, the majority of METASTROKE IS cases were recruited through acute stroke services or population studies and individuals thus are less likely to have comparable levels of atherosclerotic disease and risk. For example, in a hospital-based cohort of 4,033 stroke patients, only $10 \%$ had a history of myocardial infarction. ${ }^{4}$ Consequently, the relative contribution of different risk factors and the resulting distribution of IS subtypes may differ in the METASTROKE and randomized trial participants. A higher proportion of stroke cases in the METASTROKE metaanalysis may be due to non-atherosclerotic risk factors, such as atrial fibrillation, resulting in more cardioembolic strokes. By contrast, IS events in trials are more likely to be due to atherosclerosis resulting in a higher proportion of large artery strokes, for which therapeutic LDL-C lowering effects may have greater relevance. Such factors may also explain the stronger effects of LDL-C in randomized trials than in observational studies.

Etiologic differences in stroke may mean that even modest misclassification of IS could attenuate results, particularly given previous evidence indicating that lower LDL-C levels are associated with higher risks of hemorrhagic stroke. ${ }^{7}$ However, differential relevance of risk factors and pathways for CHD and IS as well as differences in patient characteristics between cohorts may explain some of the differences between IS and CHD observed in the present study.

Mendelian randomization analyses avoid many of the biases inherent in observational studies (e.g., confounding and reverse causation). However, such analyses rely on underlying assumptions, for example the validity of the instrument and the untestable MR-Egger INSIDE assumption, and can also suffer from weak instrument bias. To explore the robustness of the analyses, the causal effect of LDL-C on disease outcomes was estimated by various Mendelian randomization methods that relax the instrumental variable validity assumption as well as after removal of outlying variants. The analyses conducted showed no meaningful differences. Furthermore, the estimates from this Mendelian randomization study were consistent with recent reports examining the individual causal effects of LDL-C on IS and on CHD. ${ }^{13,15,37,41-43}$

This study suggests that LDL-C has a substantially weaker causal effect on IS than for CHD, a result that has potential implications for evaluation and development of therapeutic approaches. Additional large-scale genetic studies of IS, particularly with regard to specific IS subtypes and diverse ethnic populations, are needed to further elucidate these relationships. In addition, metabolomic studies may offer additional insights given that different LDL-C subparticles and their comparative pathogenicity for IS and different IS subtypes may be important given previous evidence of differences in the genetic determinants of the different particle sizes. ${ }^{44}$

\section{Acknowledgment}

Summary results for LDL-cholesterol contributed by the Global Lipids Genetics Consortium, downloaded at csg. sph.umich.edu//abecasis/public/lipids2013/. Summary results for coronary heart disease contributed by CARDIoGRAMplusC4D investigators, downloaded at CARDIOGRAMPLUSC4D.ORG. Data from METASTROKE made available through a project proposal approved by the Steering Committee. The authors thank METASTROKE of the International Stroke Genetics Consortium collaborators for contributions. Acknowledgements for each of the METASTROKE collaboration studies are provided in the supplementary material.

\section{Study funding}

Supported by the Nuffield Department of Population Health. There was no commercial funder, but the study drew on expertise developed during research funded by commercial and academic funders. The Clinical Trial Service Unit and Epidemiological Studies Unit (CTSU), Nuffield Department of Population Health, University of Oxford, receives grants from the pharmaceutical industry for research conducted independently of all sources of funding (ctsu.ox.ac.uk/aboutctsu/documents/independent-research).

\section{Disclosure}

E. Valdes-Marquez reports no disclosures relevant to the manuscript. S. Parish reports grants from the Medical Research Council, UK, during the conduct of the study and a patent for a statin-related myopathy genetic test with royalties paid to the University of Oxford and the Medical Research Council from Boston Heart Diagnostics (with 
any personal reward waived). R. Clarke reports no disclosures relevant to the manuscript. T. Stari contributed to this report while employed by University of Oxford; Traiani Stari is currently employed by Astellas. B. Worrall reports grant support from the NIH (U-01NS069208; U-01HG005160) and is Deputy Editor for Neurology ${ }^{\circledR}$. J. Hopewell reports personal fellowship support from the British Heart Foundation (FS/14/55/30806). Go to Neurology.org/N for full disclosures.

\section{Publication history}

Received by Neurology April 16, 2018. Accepted in final form November 4, 2018 .

Appendix 1 Authors

\begin{tabular}{|c|c|c|c|}
\hline Name & Location & Role & Contribution \\
\hline $\begin{array}{l}\text { Elsa } \\
\text { Valdes- } \\
\text { Marquez, } \\
\text { PhD }\end{array}$ & $\begin{array}{l}\text { Clinical Trial Service } \\
\text { Unit and } \\
\text { Epidemiological } \\
\text { Studies Unit, } \\
\text { Department of } \\
\text { Population Health, } \\
\text { University of Oxford, } \\
\text { UK }\end{array}$ & Author & $\begin{array}{l}\text { Statistical analysis; } \\
\text { drafting initial } \\
\text { manuscript; revised } \\
\text { the manuscript for } \\
\text { intellectual content }\end{array}$ \\
\hline $\begin{array}{l}\text { Sarah } \\
\text { Parish, } \\
\text { DPhil }\end{array}$ & $\begin{array}{l}\text { Clinical Trial Service } \\
\text { Unit and } \\
\text { Epidemiological } \\
\text { Studies Unit and MRC } \\
\text { Population Heath } \\
\text { Research Unit, } \\
\text { Department of } \\
\text { Population Health, } \\
\text { University of Oxford, } \\
\text { UK }\end{array}$ & Author & $\begin{array}{l}\text { Study conception; } \\
\text { drafting initial } \\
\text { manuscript; revised } \\
\text { the manuscript for } \\
\text { intellectual content }\end{array}$ \\
\hline $\begin{array}{l}\text { Robert } \\
\text { Clarke, } \\
\text { FRCP }\end{array}$ & $\begin{array}{l}\text { Clinical Trial Service } \\
\text { Unit and } \\
\text { Epidemiological } \\
\text { Studies Unit, } \\
\text { Department of } \\
\text { Population Health, } \\
\text { University of Oxford, } \\
\text { UK }\end{array}$ & Author & $\begin{array}{l}\text { Study conception; } \\
\text { revised the } \\
\text { manuscript for } \\
\text { intellectual content }\end{array}$ \\
\hline $\begin{array}{l}\text { Traiani } \\
\text { Stari, PhD }\end{array}$ & $\begin{array}{l}\text { Clinical Trial Service } \\
\text { Unit and } \\
\text { Epidemiological } \\
\text { Studies Unit, } \\
\text { Department of } \\
\text { Population Health, } \\
\text { University of Oxford, } \\
\text { UK }\end{array}$ & Author & Statistical analysis \\
\hline $\begin{array}{l}\text { Bradford } \\
\text { B. Worrall, } \\
\text { MD }\end{array}$ & $\begin{array}{l}\text { Departments of } \\
\text { Neurology and Public } \\
\text { Health Science, } \\
\text { University of Virginia } \\
\text { School of Medicine, } \\
\text { Charlottesville, VA }\end{array}$ & Author & $\begin{array}{l}\text { METASTROKE data } \\
\text { acquisition; revised } \\
\text { the manuscript for } \\
\text { intellectual content }\end{array}$ \\
\hline $\begin{array}{l}\text { Jemma C. } \\
\text { Hopewell, } \\
\text { PhD }\end{array}$ & $\begin{array}{l}\text { Clinical Trial Service } \\
\text { Unit and } \\
\text { Epidemiological } \\
\text { Studies Unit, } \\
\text { Department of } \\
\text { Population Health, } \\
\text { University of Oxford, } \\
\text { UK }\end{array}$ & Author & $\begin{array}{l}\text { Study conception; } \\
\text { METASTROKE data } \\
\text { acquisition; drafting } \\
\text { initial manuscript; } \\
\text { revised the } \\
\text { manuscript for } \\
\text { intellectual content }\end{array}$ \\
\hline
\end{tabular}

Appendix 2 METASTROKE Consortium of the ISGC: Member roles

\begin{tabular}{lll}
\hline Members & Degrees & Affiliation \\
\hline $\begin{array}{l}\text { Agnieszka } \\
\text { Slowik }\end{array}$ & MD, PhD & $\begin{array}{l}\text { Department of Neurology, } \\
\text { Jagiellonian University, Krakow, } \\
\text { Poland }\end{array}$ \\
\hline Albert Hofman & MD & $\begin{array}{l}\text { Department of Epidemiology, } \\
\text { Erasmus MC University Medical } \\
\text { Center, Rotterdam, Netherlands }\end{array}$ \\
\hline Ale Algra & MD, PhD & $\begin{array}{l}\text { Department of Neurology and } \\
\text { Neurosurgery, Utrecht Stroke } \\
\text { Center, Rudolf Magnus Institute of } \\
\text { Neuroscience, University Medical } \\
\text { Center Utrecht, Netherlands }\end{array}$ \\
& & Division of Public Health Sciences, \\
& & Fred Hutchinson Cancer Research \\
Center, Seattle, WA
\end{tabular}

\begin{tabular}{lll}
\hline $\begin{array}{l}\text { Alexander S.F. } \\
\text { Doney }\end{array}$ & PhD & $\begin{array}{l}\text { Medical Research Institute, } \\
\text { Ninewells Hospital and Medical } \\
\text { School, University of Dundee, UK }\end{array}$ \\
\hline Andreas & MD & Institute for Stroke and Dementia
\end{tabular}

Gschwendtner $\quad$ Research, Klinikum der Universitát
München, Ludwig-MaximiliansUniversität; and Munich Cluster for Systems Neurology (SyNergy), Munich, Germany

\begin{tabular}{ll}
\hline Andreea Ilinca $\quad M D$ & Department of Clinical Sciences \\
& Lund, Neurology, Lund University, \\
& Sweden
\end{tabular}

Anne-Katrin MD Department of Neurology,
Giese Massachusetts General Hospital Harvard Medical School; and J. Philip Kistler Stroke Research Center, Department of Neurology, Massachusetts General Hospital, Boston, MA

\begin{tabular}{lll}
\hline Arne Lindgren & MD, PhD & $\begin{array}{l}\text { Department of Clinical Sciences } \\
\text { Lund, Neurology, Lund University; } \\
\text { and Department of Neurology and } \\
\text { Rehabilitation Medicine, Skăne } \\
\text { University Hospital, Lund, Sweden }\end{array}$ \\
& & \\
\hline $\begin{array}{l}\text { Astrid M. } \\
\text { Vicente }\end{array}$ & PhD & $\begin{array}{l}\text { Departamento Promoção da Saúde } \\
\text { e Doenças Crónicas, Instituto } \\
\text { Nacional de Saúde Dr Ricardo Jorge, } \\
\text { Lisbon, Portugal }\end{array}$
\end{tabular}

\begin{tabular}{ll}
\hline Bo Norrving $\quad$ MD, PhD & Department of Clinical Sciences Lund, \\
& Neurology, Lund University; and \\
& Department of Neurology, Skåne \\
& University Hospital, Lund, Sweden
\end{tabular}

\begin{tabular}{|c|c|c|}
\hline $\begin{array}{l}\text { Børge G. } \\
\text { Nordestgaard }\end{array}$ & MD, DMSc & $\begin{array}{l}\text { Department of Clinical Biochemistry } \\
\text { and The Copenhagen General } \\
\text { Population Study, Herlev Hospital, } \\
\text { Copenhagen University Hospital; and } \\
\text { Faculty of Health Sciences, University } \\
\text { of Copenhagen, Denmark }\end{array}$ \\
\hline
\end{tabular}

\begin{tabular}{lll}
\hline $\begin{array}{l}\text { Braxton D. } \\
\text { Mitchell }\end{array}$ & PhD, MPH & $\begin{array}{l}\text { Department of Medicine, University } \\
\text { of Maryland School of Medicine; } \\
\text { and Geriatrics Research and } \\
\end{array}$ \\
& & $\begin{array}{l}\text { Education Clinical Center, Baltimore } \\
\text { Veterans Administration Medical } \\
\text { Center, Baltimore, MD }\end{array}$ \\
& & \\
& MD, MSC & Departments of Neurology and \\
Bradford B. & Public Health Sciences, University of \\
Worrall &
\end{tabular}


Appendix 2 (continued)

\begin{tabular}{|c|c|c|c|c|c|}
\hline Members & Degrees & Affiliation & Members & Degrees & Affiliation \\
\hline & & $\begin{array}{l}\text { Virginia School of Medicine, } \\
\text { Charlottesville, VA }\end{array}$ & $\begin{array}{l}\text { Gerard } \\
\text { Pasterkamp }\end{array}$ & $\mathrm{MD}, \mathrm{PhD}$ & $\begin{array}{l}\text { Laboratory of Experimental } \\
\text { Cardiology, University Medical } \\
\text { Center Utrecht, Netherlands }\end{array}$ \\
\hline \multirow[t]{2}{*}{ Bruce M. Psaty } & \multirow[t]{2}{*}{ MD } & \multirow{2}{*}{$\begin{array}{l}\text { Cardiovascular Health Research } \\
\text { Unit, Department of Medicine, } \\
\text { Department of Epidemiology, and } \\
\text { Department of Health Services, } \\
\text { University of Washington; and } \\
\text { Kaiser Permanente Washington } \\
\text { Health Research Institute, Seattle, } \\
\text { WA }\end{array}$} & $\begin{array}{l}\text { Giorgio B. } \\
\text { Boncoraglio }\end{array}$ & MD & $\begin{array}{l}\text { Department of Cerebrovascular } \\
\text { Diseases, Fondazione IRCCS Istituto } \\
\text { Neurologico “Carlo } 85 \text { Besta," Milan, } \\
\text { Italy }\end{array}$ \\
\hline & & & $\begin{array}{l}\text { Gregor } \\
\text { Kuhlenbäumer }\end{array}$ & $\mathrm{MD}, \mathrm{PhD}$ & $\begin{array}{l}\text { Institute for Experimental Medicine, } \\
\text { University of Kiel, Germany }\end{array}$ \\
\hline \multirow[t]{2}{*}{ Cara L. Carty } & \multirow[t]{2}{*}{ PhD } & \multirow{2}{*}{$\begin{array}{l}\text { Children's Research Institute, } \\
\text { Children's National Medical Center; } \\
\text { and Center for Translational } \\
\text { Science, George Washington } \\
\text { University, Washington, DC }\end{array}$} & $\begin{array}{l}\text { Gudmar } \\
\text { Thorleifsson }\end{array}$ & PhD & $\begin{array}{l}\text { deCODE genetics/AMGEN, } \\
\text { Reykjavik, Iceland }\end{array}$ \\
\hline & & & \multirow[t]{3}{*}{ Guido J. Falcone } & \multirow[t]{3}{*}{$\mathrm{MD}, \mathrm{ScD}, \mathrm{MPH}$} & $\begin{array}{l}\text { Division of Neurocritical Care and } \\
\text { Emergency Neurology, Department }\end{array}$ \\
\hline $\begin{array}{l}\text { Cathie L.M. } \\
\text { Sudlow }\end{array}$ & $\begin{array}{l}\text { BMBCh, MSc, } \\
\text { DPhil, FRCP } \\
\text { (Ed) }\end{array}$ & University of Edinburgh, UK & & & $\begin{array}{l}\text { of Medicine, New Haven, CT, USA; } \\
\text { and Program in Medical and } \\
\text { Population Genetics, The Broad }\end{array}$ \\
\hline \multirow{3}{*}{$\begin{array}{l}\text { Christopher } \\
\text { Anderson }\end{array}$} & \multirow[t]{3}{*}{ MD, MMSc } & \multirow{3}{*}{$\begin{array}{l}\text { Center for Genomic Medicine, } \\
\text { Massachusetts General Hospital; J. } \\
\text { Philip Kistler Stroke Research } \\
\text { Center, Department of Neurology, } \\
\text { Massachusetts General Hospital, } \\
\text { Boston; and Program in Medical } \\
\text { and Population Genetics, Broad } \\
\text { Institute, Cambridge, MA }\end{array}$} & & & Cambridge, MA \\
\hline & & & Guillaume Pare & $\mathrm{MD}, \mathrm{MSC}$ & $\begin{array}{l}\text { Population Health Research } \\
\text { Institute, McMaster University, } \\
\text { Hamilton, Canada }\end{array}$ \\
\hline & & & Helena Schmidt & $\mathrm{MD}, \mathrm{PhD}$ & $\begin{array}{l}\text { Institute of Molecular Biology and } \\
\text { Biochemistry, Medical University } \\
\text { Graz, Austria }\end{array}$ \\
\hline $\begin{array}{l}\text { Christopher R. } \\
\text { Levi }\end{array}$ & $\begin{array}{l}\text { MBBS, B Med } \\
\text { Sci, FRACP, }\end{array}$ & $\begin{array}{l}\text { Sydney Partnership for Health } \\
\text { Education Research \& Enterprise } \\
\text { (SPHERE), University of NSW } \\
\text { (Sydney); and Priority Research } \\
\text { Centre for Stroke \& Brain Injury, } \\
\text { University of Newcastle, Australia }\end{array}$ & $\begin{array}{l}\text { Hossein } \\
\text { Delavaran }\end{array}$ & $\mathrm{MD}, \mathrm{PhD}$ & $\begin{array}{l}\text { Department of Clinical Sciences } \\
\text { Lund, Neurology, Lund University; } \\
\text { and Department of Neurology, } \\
\text { Skåne University Hospital, Lund, } \\
\text { Sweden }\end{array}$ \\
\hline $\begin{array}{l}\text { Claudia L. } \\
\text { Satizabal }\end{array}$ & PhD & $\begin{array}{l}\text { Boston University School of } \\
\text { Medicine, MA }\end{array}$ & Hugh S. Markus & FRCP & $\begin{array}{l}\text { Stroke Research Group, Division of } \\
\text { Clinical Neurosciences, University } \\
\text { of Cambridge, UK }\end{array}$ \\
\hline $\begin{array}{l}\text { Colin N.A. } \\
\text { Palmer }\end{array}$ & $\mathrm{PhD}$ & $\begin{array}{l}\text { Medical Research Institute, } \\
\text { Ninewells Hospital and Medical } \\
\text { School, University of Dundee, UK }\end{array}$ & \multirow[t]{2}{*}{ Hugo J. Aparicio } & \multirow[t]{2}{*}{ MD } & $\begin{array}{l}\text { Department of Neurology, Boston } \\
\text { University School of Medicine; and } \\
\text { NHLBI's Framingham Heart Study, }\end{array}$ \\
\hline Dale M. Gamble & BS & $\begin{array}{l}\text { Department of Neurology, Mayo } \\
\text { Clinic, Jacksonville, FL }\end{array}$ & & & MA \\
\hline Daniel Woo & MD & $\begin{array}{l}\text { University of Cincinnati College of } \\
\text { Medicine, } \mathrm{OH}\end{array}$ & בe & PhD & $\begin{array}{l}\text { Department of Psychology and } \\
\text { Centre for Cognitive Ageing and } \\
\text { Cognitive Epidemiology, University } \\
\text { of Edinburgh, UK }\end{array}$ \\
\hline $\begin{array}{l}\text { Danish } \\
\text { Saleheen }\end{array}$ & PhD & $\begin{array}{l}\text { Department of Genetics, Perelman } \\
\text { School of Medicine, University of } \\
\text { Pennsylvania, Philadelphia, PA }\end{array}$ & Ioana Cotlarciuc & PhD & $\begin{array}{l}\text { Institute of Cardiovascular } \\
\text { Research, Royal Holloway } \\
\text { University of London, UK }\end{array}$ \\
\hline $\begin{array}{l}\text { E. Bernd } \\
\text { Ringelstein }\end{array}$ & MD & $\begin{array}{l}\text { Department of Neurology, } \\
\text { University of Münster, Germany }\end{array}$ & \multirow{3}{*}{$\begin{array}{l}\text { Israel } \\
\text { Fernandez- } \\
\text { Cadenas }\end{array}$} & \multirow[t]{3}{*}{ PhD } & Neurovascular Research \\
\hline $\begin{array}{l}\text { Einar M. } \\
\text { Valdimarsson }\end{array}$ & MD & $\begin{array}{l}\text { Landspitali, University Hospital, } \\
\text { Reykjavik, Iceland }\end{array}$ & & & $\begin{array}{l}\text { of Research, Neurology and } \\
\text { Medicine Departments, Universitat } \\
\text { Autònoma de Barcelona, Vall }\end{array}$ \\
\hline $\begin{array}{l}\text { Elizabeth G. } \\
\text { Holliday }\end{array}$ & $\mathrm{PhD}$ & $\begin{array}{l}\text { Public Health Stream, Hunter } \\
\text { Medical Research Institute, New } \\
\text { Lambton; and Faculty of Health and } \\
\text { Medicine, University of Newcastle, } \\
\text { Australia }\end{array}$ & & & $\begin{array}{l}\text { d'Hebrón Hospital, Barcelona; and } \\
\text { Stroke Pharmacogenomics and } \\
\text { Genetics, Fundacio Docència i } \\
\text { Recerca Mutua Terrassa, Terrassa, } \\
\text { Spain }\end{array}$ \\
\hline \multirow[t]{2}{*}{ Gail Davies } & \multirow[t]{2}{*}{ PhD } & \multirow{2}{*}{$\begin{array}{l}\text { Department of Psychology and } \\
\text { Centre for Cognitive Ageing and } \\
\text { Cognitive Epidemiology, University } \\
\text { of Edinburgh, UK }\end{array}$} & $\begin{array}{l}\text { James F. } \\
\text { Meschia }\end{array}$ & MD & $\begin{array}{l}\text { Department of Neurology, Mayo } \\
\text { Clinic, Jacksonville, FL }\end{array}$ \\
\hline & & & $\begin{array}{l}\text { Jemma C. } \\
\text { Hopewell }\end{array}$ & PhD & $\begin{array}{l}\text { CTSU, Nuffield Department of } \\
\text { Population Health University of }\end{array}$ \\
\hline $\begin{array}{l}\text { Ganesh } \\
\text { Chauhan }\end{array}$ & $\mathrm{PhD}$ & $\begin{array}{l}\text { Centre for Brain Research, Indian } \\
\text { Institute of Science, Bangalore, }\end{array}$ & & & Oxford, UK \\
\hline
\end{tabular}

Appendix 2 (continued) . 
Appendix 2 (continued)

\begin{tabular}{|c|c|c|c|c|c|}
\hline Members & Degrees & Affiliation & Members & Degrees & Affiliation \\
\hline Jingmin Liu & MS & $\begin{array}{l}\text { Fred Hutchinson Cancer Research } \\
\text { Center, Seattle, WA }\end{array}$ & & & $\begin{array}{l}\text { München, Ludwig-51 Maximilians- } \\
\text { University, Munich, Germany }\end{array}$ \\
\hline \multirow[t]{2}{*}{ Joan Montaner } & \multirow[t]{2}{*}{ MD } & \multirow{2}{*}{$\begin{array}{l}\text { Neurovascular Research } \\
\text { Laboratory, Neurology and } \\
\text { Medicine Departments, Universitat } \\
\text { Autònoma de Barcelona and } \\
\text { Institute of Research Vall d'Hebrón } \\
\text { Hospital, Barcelona, Spain }\end{array}$} & Martin Farrall & FRCPath & $\begin{array}{l}\text { Department of Cardiovascular } \\
\text { Medicine, University of Oxford, UK }\end{array}$ \\
\hline & & & $\begin{array}{l}\text { Massimo } \\
\text { Pandolfo }\end{array}$ & MD & $\begin{array}{l}\text { Laboratory of Experimental } \\
\text { Neurology, Brussels, Belgium }\end{array}$ \\
\hline Joanna Pera & $\mathrm{MD}, \mathrm{PhD}$ & $\begin{array}{l}\text { Department of Neurology, } \\
\text { Jagiellonian University, Krakow, } \\
\text { Poland }\end{array}$ & $\begin{array}{l}\text { Matthew } \\
\text { Traylor }\end{array}$ & PhD & $\begin{array}{l}\text { Stroke Research Group, Division of } \\
\text { Clinical Neurosciences, University } \\
\text { of Cambridge, UK }\end{array}$ \\
\hline John Cole & MD & $\begin{array}{l}\text { Department of Neurology, } \\
\text { University of Maryland School } \\
\text { of Medicine and Baltimore } \\
\text { VAMC }\end{array}$ & $\begin{array}{l}\text { Matthew } \\
\text { Walters }\end{array}$ & MS & $\begin{array}{l}\text { School of Medicine, Dentistry and } \\
\text { Nursing at the University of } \\
\text { Glasgow, UK }\end{array}$ \\
\hline John R. Attia & $\begin{array}{l}\text { MD, PhD, } \\
\text { FRACP, FRCPC }\end{array}$ & $\begin{array}{l}\text { Hunter Medical Research Institute } \\
\text { Public Health Research Program, } \\
\text { Newcastle, Australia }\end{array}$ & Michele Sale & PhD & $\begin{array}{l}\text { Center for Public Health Genomics, } \\
\text { University of Virginia, } \\
\text { Charlottesville, VA }\end{array}$ \\
\hline \multirow[t]{3}{*}{$\begin{array}{l}\text { Jonathan } \\
\text { Rosand }\end{array}$} & \multirow[t]{3}{*}{$\mathrm{MD}, \mathrm{MSC}$} & \multirow{3}{*}{$\begin{array}{l}\text { Center for Genomic Medicine, } \\
\text { Massachusetts General Hospital; } \\
\text { J. Philip Kistler Stroke Research } \\
\text { Center, Department of } \\
\text { Neurology, Massachusetts } \\
\text { General Hospital, Boston; and } \\
\text { Program in Medical and } \\
\text { Population Genetics, Broad } \\
\text { Institute, Cambridge, MA }\end{array}$} & Michael A. Nalls & PhD & $\begin{array}{l}\text { Laboratory of Neurogenetics, } \\
\text { National Institute on Aging, NIH, } \\
\text { Bethesda; and Data Tecnica } \\
\text { International, Glen Echo, MD }\end{array}$ \\
\hline & & & Myriam Fornage & PhD & $\begin{array}{l}\text { Brown Foundation Institute of } \\
\text { Molecular Medicine and Human } \\
\text { Genetics Center, University of Texas } \\
\text { Health Science Center at Houston }\end{array}$ \\
\hline & & & Natalie R. van & PhD & Medical Research Institute, \\
\hline \multirow[t]{2}{*}{ Jose M. Ferro } & \multirow[t]{2}{*}{$\mathrm{MD}, \mathrm{PhD}$} & \multirow{2}{*}{$\begin{array}{l}\text { Serviço de Neurologia, Centro de } \\
\text { Estudos Egas Moniz, Hospital de } \\
\text { Santa Maria, Lisbon, Portugal }\end{array}$} & & & School, University of Dundee, UK \\
\hline & & & Pankaj Sharma & $\mathrm{MD}, \mathrm{PhD}$ & Institute of Cardiovascular \\
\hline \multirow[t]{2}{*}{ Joshua C. Bis } & \multirow[t]{2}{*}{ PhD } & \multirow{2}{*}{$\begin{array}{l}\text { Cardiovascular Health Research } \\
\text { Unit, Department of Medicine, } \\
\text { University of Washington, Seattle }\end{array}$} & & & University of London, UK \\
\hline & & & $\begin{array}{l}\text { Patricia } \\
\text { Abrantes }\end{array}$ & PhD & $\begin{array}{l}\text { Instituto de Medicina Molecular, } \\
\text { Faculdade de Medicina, }\end{array}$ \\
\hline \multirow[t]{2}{*}{ Karen Furie } & \multirow[t]{2}{*}{ MD } & \multirow{2}{*}{$\begin{array}{l}\text { Department of Neurology, } \\
\text { Massachusetts General Hospital, } \\
\text { Boston }\end{array}$} & & & Universidade de Lisboa, Portugal \\
\hline & & & $\begin{array}{l}\text { Paul I.W. de } \\
\text { Bakker }\end{array}$ & PhD & $\begin{array}{l}\text { Department of Medical Genetics } \\
\text { and Department of Epidemiology }\end{array}$ \\
\hline Kari Stefansson & $\mathrm{MD}, \mathrm{PhD}$ & $\begin{array}{l}\text { deCODE genetics/AMGEN; and } \\
\text { Faculty of Medicine, University of } \\
\text { Iceland, Reykjavik }\end{array}$ & & & $\begin{array}{l}\text { Julius Center for Health Sciences } \\
\text { and Primary Care, University } \\
\text { Medical Center Utrecht, } \\
\text { Netherlands }\end{array}$ \\
\hline Klaus Berger & MD & $\begin{array}{l}\text { Institute of Epidemiology and Social } \\
\text { Medicine, University of Münster, } \\
\text { Germany }\end{array}$ & Peter Higgins & MRCP & $\begin{array}{l}\text { Institute of Cardiovascular and } \\
\text { Medical Sciences, University of } \\
\text { Glasgow, UK }\end{array}$ \\
\hline $\begin{array}{l}\text { Konstantinos } \\
\text { Kostulas }\end{array}$ & $\mathrm{MD}, \mathrm{PhD}$ & $\begin{array}{l}\text { Department of Neurology, } \\
\text { Karolinska Institutet at Karolinska } \\
\text { University Hospital, Huddinge, } \\
\text { Sweden }\end{array}$ & Peter Lichtner & PhD & $\begin{array}{l}\text { Helmholtz Zentrum München and } \\
\text { Technische Universität München, } \\
\text { Institut für Humangenetik, Munich, } \\
\text { Germany }\end{array}$ \\
\hline $\begin{array}{l}\text { Kristiina } \\
\text { Rannikmae }\end{array}$ & $\mathrm{MD}, \mathrm{PhD}$ & $\begin{array}{l}\text { Centre for Clinical Brain Sciences, } \\
\text { University of Edinburgh, UK }\end{array}$ & $\begin{array}{l}\text { Peter M. } \\
\text { Rothwell }\end{array}$ & $\begin{array}{l}\text { MD, PhD, } \\
\text { FMedSci }\end{array}$ & $\begin{array}{l}\text { Nuffield Department of Clinical } \\
\text { Neurosciences, University of }\end{array}$ \\
\hline M. Arfan Ikram & $\mathrm{MD}, \mathrm{PhD}$ & $\begin{array}{l}\text { Department of Epidemiology, } \\
\text { Erasmus University Medical Center, }\end{array}$ & & & Oxford, UK \\
\hline & & Rotterdam, Netherlands & $\begin{array}{l}\text { Philippe } \\
\text { Amouyel }\end{array}$ & $\mathrm{MD}, \mathrm{PhD}$ & $\begin{array}{l}\text { INSERM U1167, Institut Pasteur de } \\
\text { Lille; and Department of Public }\end{array}$ \\
\hline Marianne Benn & $\begin{array}{l}\text { MD, DMSc, } \\
\text { PhD }\end{array}$ & $\begin{array}{l}\text { Department of Clinical } \\
\text { Biochemistry and The Copenhagen } \\
\text { General Population Study, Herlev }\end{array}$ & & & $\begin{array}{l}\text { Health, Lille University Hospital, } \\
\text { France }\end{array}$ \\
\hline & & $\begin{array}{l}\text { Hospital, Copenhagen University } \\
\text { Hospital, and Faculty of Health } \\
\text { Sciences, University of Copenhagen, }\end{array}$ & Qiong Yang & PhD & $\begin{array}{l}\text { Boston University School of Public } \\
\text { Health, MA }\end{array}$ \\
\hline & & Denmark & Rainer Malik & PhD & $\begin{array}{l}\text { Institute for Stroke and Dementia } \\
\text { Research, Klinikum der Universität }\end{array}$ \\
\hline Martin Dichgans & MD & $\begin{array}{l}\text { Institute for Stroke and Dementia } \\
\text { Research, Klinikum der Universität }\end{array}$ & & & $\begin{array}{l}\text { München, Ludwig-51 Maximilians- } \\
\text { University, Munich, Germany }\end{array}$ \\
\hline
\end{tabular}

Continued 
Appendix 2 (continued)

\begin{tabular}{lll}
\hline Members & Degrees & Affiliation \\
\hline $\begin{array}{l}\text { Reinhold } \\
\text { Schmidt }\end{array}$ & MD & $\begin{array}{l}\text { Department of Neurology, Medical } \\
\text { University of Graz, Austria }\end{array}$ \\
\hline Robert Clarke & FRCP & $\begin{array}{l}\text { CTSU, Nuffield Department of } \\
\text { Population Health, University of } \\
\text { Oxford, UK }\end{array}$
\end{tabular}

Robin Lemmens $M D, P h D$

Experimental Neurology, Department of Neurosciences, KU Leuven-University of Leuven; and Department of Neurology, VIB Center for Brain \& Disease Research, University Hospitals, Leuven, Belgium

\begin{tabular}{|c|c|c|}
\hline $\begin{array}{l}\text { Sander W. van } \\
\text { der Laan }\end{array}$ & $\mathrm{PhD}$ & $\begin{array}{l}\text { Laboratory of Experimental } \\
\text { Cardiology, Division of Heart and } \\
\text { Lungs, University Medical Center } \\
\text { Utrecht, Netherlands }\end{array}$ \\
\hline
\end{tabular}

\begin{tabular}{ll}
\hline Sara L. Pulit $\quad$ PhD & Brain Center Rudolf Magnus, \\
& Department of Neurology, \\
& University Medical Center Utrecht, \\
& Netherlands
\end{tabular}

\begin{tabular}{lll}
\hline Sherine Abboud & MD, PhD & $\begin{array}{l}\text { Laboratory of Experimental } \\
\text { Neurology, Brussels, Belgium }\end{array}$ \\
\hline Sofia A. Oliveira & PhD & $\begin{array}{l}\text { Instituto de Medicina Molecular, } \\
\text { Faculdade de Medicina da } \\
\text { Universidade de Lisboa, Lisbon, } \\
\text { Portugal }\end{array}$
\end{tabular}

\begin{tabular}{lll}
\hline $\begin{array}{l}\text { Solveig } \\
\text { Gretarsdottir }\end{array}$ & PhD & $\begin{array}{l}\text { deCODE genetics/AMGEN, } \\
\text { Reykjavik, Iceland }\end{array}$ \\
\hline $\begin{array}{l}\text { Stephanie } \\
\text { Debette }\end{array}$ & MD, PhD & $\begin{array}{l}\text { INSERM U1219 Bordeaux } \\
\text { Population Health Research Center; } \\
\text { and University of Bordeaux, France }\end{array}$ \\
\hline $\begin{array}{l}\text { Stephen R. } \\
\text { Williams }\end{array}$ & PhD & $\begin{array}{l}\text { Department of Neurology, } \\
\text { University of Virginia, } \\
\text { Charlottesville, VA }\end{array}$ \\
\hline Steve Bevan & PhD & $\begin{array}{l}\text { School of Life Science, University of } \\
\text { Lincoln, UK }\end{array}$ \\
\hline
\end{tabular}

\begin{tabular}{ll}
\hline Steven J. Kittner $\quad M D, M P H$ & $\begin{array}{l}\text { Department of Neurology, } \\
\text { University of Maryland School of } \\
\text { Medicine and Baltimore VAMC }\end{array}$
\end{tabular}

\begin{tabular}{ll}
\hline Sudha Seshadri $\quad$ MD & Department of Neurology, Boston \\
& University School of Medicine; and \\
& Framingham Heart Study, MA
\end{tabular}

Thomas Mosley PhD Division of Geriatrics, School of Medicine, and Memory Impairment and Neurodegenerative Dementia Center, University of Mississippi Medical Center, Jackson

\begin{tabular}{lll}
\hline $\begin{array}{l}\text { Thomas W.K. } \\
\text { Battey }\end{array}$ & BS & $\begin{array}{l}\text { Division of Neurocritical Care and } \\
\text { Emergency Neurology, Department } \\
\text { of Neurology, Center for Human } \\
\text { Genetic Research, Massachusetts } \\
\text { General Hospital, Boston }\end{array}$ \\
\hline $\begin{array}{l}\text { Turgut } \\
\text { Tatlisumak }\end{array}$ & MD, PhD & $\begin{array}{l}\text { Department of Clinical } \\
\text { Neurosciences/Neurology, Institute } \\
\text { of Neuroscience and Physiology, } \\
\text { Sahlgrenska Academy at University } \\
\text { of Gothenburg, Sweden }\end{array}$ \\
\hline $\begin{array}{l}\text { Unnur } \\
\text { Thorsteinsdottir }\end{array}$ & PhD & $\begin{array}{l}\text { deCODE genetics/AMGEN; and } \\
\text { Faculty of Medicine, University of } \\
\text { Iceland, Reykjavik }\end{array}$ \\
\hline
\end{tabular}

Appendix 2 (continued)

\begin{tabular}{lll}
\hline Members & Degrees & Affiliation \\
\hline $\begin{array}{l}\text { Vincent N.S. } \\
\text { Thijs }\end{array}$ & MD, PhD & $\begin{array}{l}\text { Stroke Division, Florey Institute of } \\
\text { Neuroscience and Mental Health; } \\
\text { and Austin Health, Department of } \\
\text { Neurology, Heidelberg, Australia }\end{array}$ \\
\hline W.T. Longstreth & MD & $\begin{array}{l}\text { Departments of Epidemiology and } \\
\text { Neurology, University of } \\
\text { Washington, Seattle }\end{array}$ \\
\hline Wei Zhao & MD, PhD & $\begin{array}{l}\text { Department of Genetics, Perelman } \\
\text { School of Medicine, University of } \\
\text { Pennsylvania, Philadelphia, PA }\end{array}$ \\
\hline Wei-Min Chen & PhD & $\begin{array}{l}\text { Center for Public Health Genomics, } \\
\text { Department of Public Health } \\
\text { Sciences, University of Virginia } \\
\text { School of Medicine, Charlottesville }\end{array}$ \\
\hline Yu-Ching Cheng & PhD & $\begin{array}{l}\text { Department of Medicine, University } \\
\text { of Maryland School of Medicine, } \\
\text { Baltimore, MD }\end{array}$ \\
& &
\end{tabular}

These members made contributions to the METASTROKE Consortium and to previously published METASTROKE genome-wide association metaanalyses, data collection, and wider scientific input. Jemma Hopewell was the Chair of the METASTROKE Consortium at the time of publication. Sudha Seshadri is the immediate past Chair of the METASTROKE Consortium.

\section{References}

1. Markus HS. Stroke genetics. Hum Mol Genet 2011;20:R124-R131.

2. O'Donnell MJ, Chin SL, Rangarajan S, et al. Global and regional effects of potentially modifiable risk factors associated with acute stroke in 32 countries (INTERSTROKE): a case-control study. Lancet 2016;388:761-775.

3. Bevan S, Traylor M, Adib-Samii P, et al. Genetic heritability of ischemic stroke and the contribution of previously reported candidate gene and genomewide associations. Stroke 2012;43:3161-3167.

4. Hauer AJ, Ruigrok YM, Algra A, et al. Age-specific vascular risk factor profiles according to stroke subtype. J Am Heart Assoc 2017;6:005090.

5. Malik R, Traylor M, Pulit SL, et al. Low-frequency and common genetic variation in ischemic stroke: the METASTROKE collaboration. Neurology 2016;86:1217-1226.

6. Schulz UG, Rothwell PM. Differences in vascular risk factors between etiological subtypes of ischemic stroke: importance of population-based studies. Stroke 2003;34: 2050-2059.

7. Baigent C, Blackwell L, Emberson J, et al. Efficacy and safety of more intensive lowering of LDL cholesterol: a meta-analysis of data from 170,000 participants in 26 randomised trials. Lancet 2010;376:1670-1681.

8. Sabatine MS, Giugliano RP, Keech AC, et al. Evolocumab and clinical outcomes in patients with cardiovascular disease. N Engl J Med 2017;376:1713-1722.

9. Cannon CP, Blazing MA, Giugliano RP, et al. Ezetimibe added to statin therapy after acute coronary syndromes. N Engl J Med 2015;372:2387-2397.

10. Di Angelantonio E, Sarwar N, Perry P, et al. Major lipids, apolipoproteins, and risk of vascular disease. JAMA 2009;302:1993-2000.

11. Ference BA, Majeed F, Penumetcha R, Flack JM, Brook RD. Effect of naturally random allocation to lower low-density lipoprotein cholesterol on the risk of coronary heart disease mediated by polymorphisms in NPC1L1, HMGCR, or both: a 2 x 2 factorial Mendelian randomization study. J Am Coll Cardiol 2015;65:1552-1561.

12. Ference BA, Yoo W, Alesh I, et al. Effect of long-term exposure to lower low-density lipoprotein cholesterol beginning early in life on the risk of coronary heart disease: a Mendelian randomization analysis. J Am Coll Cardiol 2012;60:2631-2639.

13. Holmes MV, Asselbergs FW, Palmer TM, et al. Mendelian randomization of blood lipids for coronary heart disease. Eur Heart J 2015;36:539-550.

14. Jansen H, Samani NJ, Schunkert H. Mendelian randomization studies in coronary artery disease. Eur Heart J 2014;35:1917-1924.

15. Hindy G, Engstrom G, Larsson SC, et al. Role of blood lipids in the development of ischemic stroke and its subtypes: a Mendelian randomization study. Stroke 2018;49: 820-827.

16. Hopewell JC, Clarke R. Emerging risk factors for stroke: what have we learned from Mendelian randomization studies? Stroke 2016;47:1673-1678.

17. Larsson SC, Scott RA, Traylor M, et al. Type 2 diabetes, glucose, insulin, BMI, and ischemic stroke subtypes: Mendelian randomization study. Neurology 2017;89:454-460.

18. Willer CJ, Schmidt EM, Sengupta S, et al. Discovery and refinement of loci associated with lipid levels. Nat Genet 2013;45:1274-1283.

19. Nikpay M, Goel A, Won HH, et al. A comprehensive 1,000 Genomes-based genome-wide association meta-analysis of coronary artery disease. Nat Genet 2015;47:1121-1130. 
20. Traylor M, Farrall M, Holliday EG, et al. Genetic risk factors for ischaemic stroke and its subtypes (the METASTROKE collaboration): a meta-analysis of genome-wide association studies. Lancet Neurol 2012;11:951-962.

21. Adams HP Jr., Bendixen BH, Kappelle LJ, et al. Classification of subtype of acute ischemic stroke. Definitions for use in a multicenter clinical trial. TOAST. Trial of Org 10172 in Acute Stroke Treatment. Stroke 1993;24:35-41.

22. Auton A, Brooks LD, Durbin RM, et al. A global reference for human genetic variation. Nature 2015;526:68-74.

23. Chang CC, Chow CC, Tellier LC, et al. Second-generation PLINK: rising to the challenge of larger and richer datasets. Gigascience 2015;4:015-0047.

24. Burgess S, Dudbridge F, Thompson SG. Combining information on multiple instrumental variables in Mendelian randomization: comparison of allele score and summarized data methods. Stat Med 2016;35:1880-1906.

25. Burgess S. Sample size and power calculations in Mendelian randomization with a single instrumental variable and a binary outcome. Int J Epidemiol 2014;43:922-929.

26. Burgess S, Butterworth A, Thompson SG. Mendelian randomization analysis with multiple genetic variants using summarized data. Genet Epidemiol 2013;37: 658-665.

27. Burgess S, Bowden J, Fall T, Ingelsson E, Thompson SG. Sensitivity analyses for robust causal inference from Mendelian randomization analyses with multiple genetic variants. Epidemiology 2017;28:30-42.

28. Haycock PC, Burgess S, Wade $\mathrm{KH}$, et al. Best (but oft-forgotten) practices: the design, analysis, and interpretation of Mendelian randomization studies. Am J Clin Nutr 2016;103:965-978.

29. Bowden J, Davey Smith G, Burgess S. Mendelian randomization with invalid instruments: effect estimation and bias detection through Egger regression. Int J Epidemiol 2015;44:512-525.

30. Burgess S, Thompson SG. Interpreting findings from Mendelian randomization using the MR-Egger method. Eur J Epidemiol 2017;32:377-389.

31. Bowden J, Davey Smith G, Haycock PC, Burgess S. Consistent estimation in Mendelian randomization with some invalid instruments using a weighted median estimator. Genet Epidemiol 2016;40:304-314.

32 Burgess S, Thompson SG. Multivariable Mendelian randomization: the use of pleiotropic genetic variants to estimate causal effects. Am J Epidemiol 2015;181:251-260.
33. Verbanck M, Chen CY, Neale B, Do R. Detection of widespread horizontal pleiotropy in causal relationships inferred from Mendelian randomization between complex traits and diseases. Nat Genet 2018;50:693-698.

34. Bogiatzi C, Hackam DG, McLeod AI, Spence JD. Secular trends in ischemic stroke subtypes and stroke risk factors. Stroke 2014;45:3208-3213.

35. Amarenco P, Benavente O, Goldstein LB, et al. Results of the Stroke Prevention by Aggressive Reduction in Cholesterol Levels (SPARCL) trial by stroke subtypes. Stroke 2009; 40:1405-1409.

36. Ference BA. How to use Mendelian randomization to anticipate the results of randomized trials. Eur Heart J 2018;39:360-362.

37. Ference BA, Robinson JG, Brook RD, et al. Variation in PCSK9 and HMGCR and risk of cardiovascular disease and diabetes. N Engl J Med 2016;375:2144-2153.

38. Hopewell JC, Malik R, Valdes-Marquez E, Worrall BB, Collins R. Differential effects of PCSK9 variants on risk of coronary disease and ischaemic stroke. Eur Heart J 2018; 39:354-359.

39. Ference BA, Kastelein JJP, Ginsberg HN, et al. Association of genetic variants related to CETP inhibitors and statins with lipoprotein levels and cardiovascular risk. JAMA 2017;318:947-956.

40. Mihaylova B, Emberson J, Blackwell L, et al. The effects of lowering LDL cholesterol with statin therapy in people at low risk of vascular disease: meta-analysis of individual data from 27 randomised trials. Lancet 2012;380:581-590.

41. Burgess S, Davey Smith G. Mendelian randomization implicates high-density lipoprotein cholesterol-associated mechanisms in etiology of age-related macular degeneration. Ophthalmology 2017;124:1165-1174.

42. Xu L, Borges MC, Hemani G, Lawlor DA. The role of glycaemic and lipid risk factors in mediating the effect of BMI on coronary heart disease: a two-step, two-sample Mendelian randomisation study. Diabetologia 2017;60:2210-2220.

43. Zhu Z, Zheng Z, Zhang F, et al. Causal associations between risk factors and common diseases inferred from GWAS summary data. Nat Commun 2018;9:224.

44. Chasman DI, Pare G, Mora S, et al. Forty-three loci associated with plasma lipoprotein size, concentration, and cholesterol content in genome-wide analysis. PLoS Genet 2009;5:e1000730. 


\section{Neurology}

\section{Relative effects of LDL-C on ischemic stroke and coronary disease: A Mendelian randomization study}

Elsa Valdes-Marquez, Sarah Parish, Robert Clarke, et al.

Neurology 2019;92;e1176-e1187 Published Online before print February 20, 2019

DOI 10.1212/WNL.0000000000007091

This information is current as of February 20, 2019

Updated Information \& Services

References

Subspecialty Collections

Permissions \& Licensing

Reprints including high resolution figures, can be found at: http://n.neurology.org/content/92/11/e1176.full

This article cites 44 articles, 12 of which you can access for free at: http://n.neurology.org/content/92/11/e1176.full\#ref-list-1

This article, along with others on similar topics, appears in the following collection(s):

Risk factors in epidemiology

http://n.neurology.org/cgi/collection/risk_factors_in_epidemiology Stroke prevention

http://n.neurology.org/cgi/collection/stroke_prevention

Information about reproducing this article in parts (figures,tables) or in its entirety can be found online at:

http://www.neurology.org/about/about_the_journal\#permissions

Information about ordering reprints can be found online:

http://n.neurology.org/subscribers/advertise

Neurology ${ }^{\circledR}$ is the official journal of the American Academy of Neurology. Published continuously since 1951, it is now a weekly with 48 issues per year. Copyright Copyright ( $) 2019$ The Author(s). Published by Wolters Kluwer Health, Inc. on behalf of the American Academy of Neurology.. All rights reserved. Print ISSN: 0028-3878. Online ISSN: 1526-632X.

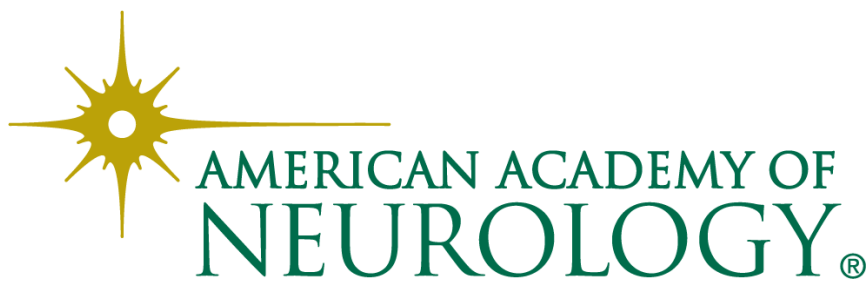

